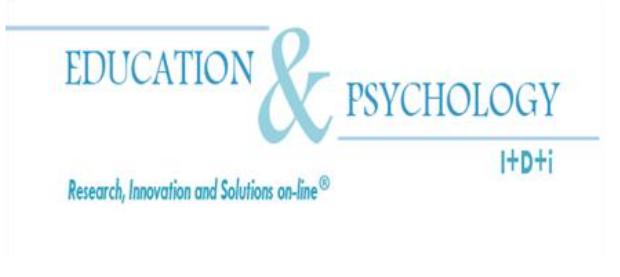

\title{
Academic Writing Practices in Spanish Universities
}

\section{Montserrat Castelló ${ }^{1}$, Mar Mateos ${ }^{2}$, Núria Castells ${ }^{3}$, Anna Iñesta ${ }^{4}$, Isabel Cuevas ${ }^{2}$, Isabel Solé ${ }^{3}$}

${ }^{1}$ Graduate School of Psychology, Educational Sciences and Sport. Blanquerna. Ramon Llull University. Barcelona

${ }^{2}$ Graduate School of Psychology. Autonoma University of Madrid

${ }^{3}$ Graduate School of Psychology.University of Barcelona

${ }^{4}$ ESADE Business School. Ramon Llull University. Barcelona

\section{Spain}

Correspondence: Montserrat Castelló. Graduate School of Psychology, Educational Sciences and Sport. Blanquerna.Ramon Llull University. Cister, 34. 08022. Barcelona. Spain. E-mail: montserratcb@blanquerna.url.edu

(C) Education \& Psychology I+D+i and Editorial EOS (Spain) 


\begin{abstract}
Introduction. This article aims at describing the use of written genres at university and how they are used to teach and learn.

Method. We carried out a descriptive study focusing on teachers' perceptions regarding the importance of academic writing in promoting learning, the degree of competence they attribute to academic writing in comparison to other academic competences, the academic writing tasks most assigned and the criteria used to assess the quality of an academic text. Participants in this study were 106 teachers from 4 Spanish universities. Data was collected trough a translated and adapted version of the Writing Skills Appreciation Inventory.
\end{abstract}

Results. Results offer a complex picture. On the one hand, teachers value writing-to-learn in their disciplines, but they do not ask students to write very frequently. On the other hand, teachers consider that students are not competent enough to use writing as a learning tool. Although they recognise the importance of writing to learn they are not used to reflect on how to use it in their disciplines. Moreover, while the presence of a clear, personal point of view is also one of the highly valued criteria for teachers, data also show that among the less valued criteria are forceful defense of a thesis or grasping the effect of the text on the reader, which seems to be clearly contradictory.

Discussion and conclusions. Results offer some contradictions between the teachers' percepción about academic writing and the role that writing has in their practices. Educational implications are discussed.

Keywords: Academic Writing; Writing Practices; Writing to Learn; Higher Education; Teachers' Conceptions 


\section{Prácticas de redacción académica en las universidades españolas}

\section{Resumen}

Introducción. En este articulo nos centramos en la naturaleza de los géneros escritos más usados en la universidad y cómo se utilizan en los procesos de enseñanza y aprendizaje.

Método. Se realizó un estudio descriptivo sobre las percepciones del profesorado universitario respecto a los siguientes aspectos relacionados con la escritura académica: el grado de importancia en el aprendizaje, el grado de competencia que atribuyen a sus estudiantes en el dominio de la escritura académica en comparación con otras competencias, el tipo de tareas de escritura más habituales y los criterios utilizados para evaluar la calidad de un texto académico. Los participantes fueron 106 profesores de 4 universidades españolas que respondieron a una versión traducida y adaptada del Writing Skills Appreciation Inventory.

Resultados. Los resultados ofrecen un panorama complejo. Por un lado, si bien los profesores valoran la escritura como una herramienta útil para aprender en sus respectivas disciplinas, no solicitan a menudo este tipo de escritura. A pesar de que reconocen la importancia de la escritura para aprender no están acostumbrados a reflexionar sobre su uso en sus respectivas disciplinas. Por otro lado, los profesores consideran a los estudiantes poco competentes para utilizar la escritura como herramienta de aprendizaje, y, mientras que la presencia de un punto de vista personal es muy valorado por los profesores, la defensa enérgica de una tesis o la preocupación por el efecto del texto en el lector, están entre los criterios menos valorados.

Discusión y Conclusión. En el texto se analizan las implicaciones educativas que se derivan de dichas percpeciones y cómo estas implicaciones educativas nos acercan a los planteamientso del EEES respecto al aprendizaje de competencias

Palabras Clave: Escritura académica; prácticas de escritura; escribir para aprender; Educación Superior; Concepciones del profesorado. 


\section{Introduction}

The writing process has been a privileged research topic from the studies of Flower \& Hayes (1980) and Bereiter \& Scardamalia (1987), which described the cognitive operations involved in such processes. From the publication of such pioneering studies, the contributions made from psychology, psycholinguistics, sociolinguistics and pragmatics have managed to incorporate a contextual dimension to the explanation of the composition processes, where social and cultural contexts, the objectives aimed at by the writer and his/her attitudes towards writing appear as constituting elements of such processes. From this perspective, we understand writing as a discursive, dialogic and situated activity that members of a specific community develop within a social, cultural and historical context (Castelló, 2007).

Entering the university involves becoming part of the academic community, where undergraduate students are confronted with new reading and writing demands requiring competences not necessarily transferrable from previous learning experiences. The expositoryargumentative text and its academically characteristic intertextuality (Teberosky, 2007) poses the university student an important challenge, both in terms of understanding (while reading) and producing (while writing). The tasks they need to solve frequently involve reading and synthesizing information from multiple academic or scientific sources in their original text, which can be considered a very cognitively demanding task (Mateos, 2009; Mateos y Solé, 2009; Nelson, 2007). The progressive domain in a disciplinary field requires the competent use of the procedures of elaboration and communication characteristics of that field, which is why it is necessary to articulate educational proposals where students as participating members of the academic community can learn to understand and elaborate written texts through their practice in authentic discursive practices where experts facilitate the progressive appropriation of such procedures. Such practices should promote (Castelló, 2009): a conception and use of writing as a learning and thinking tool; the knowledge and regulation of the processes involved in academic writing; and the use and elaboration of the texts belonging to a specific discursive community.

The Bologna process has brought with it an increasing interest in the kind of writing practices developed in the context of university education. This constitutes a major challenge for most of the European countries and universities since in some cases there is a lack of studies and traditions in analysing these writing practices, and research comparing these traditions is even more scarce (Chitez \& Kruse, 2012). This article aims to contribute to enhance our 
knowledge regarding the academic writing practices in Spain and is part of a larger European study focusing on the writing cultures in different European countries, the written genres most used at university and how they are used to teach and learn ${ }^{1}$.

Understanding both aspects, though, requires a previous contextualization in order to know how university teaching is organized in every country, and which characteristics of this education are the most relevant. In Spain, the different Autonomous Communities (regions) have authority on university education. This means that, although there is a general regulation for the entire Spanish territory, these Communities make specific decisions concerning the university context, following a decentralized model. Moreover, although Spanish is the official language of higher education, in some Autonomous Communities there are other coofficial languages. Thus, Catalan is used in Catalonia, the Balearic Islands, and the Valencian Community (Valencian), Galician is used in Galicia, and Basque in the Basque Country. Both Spanish and the other co-official languages are used orally and in writing. As for the use of other languages in university writing, in the absence of specific studies that provide more accurate accounts, the entrance into the European Higher Education Area has produced a remarkable amount of dissertations in accordance with the European Doctorate, which implies that at least a part of these doctoral theses has been written in the official language of another European Union member state -for example, in English-.

Concerning the kind of writing practices developed at the university, in our country there are data from a study by the LEAC research group carried out at three different educational levels: compulsory secondary education, post-compulsory secondary education, and university education (Mateos, Villalón, de Dios, \& Martín, 2007; Solé, Mateos, Miras, Martin, Cuevas, Castells, \& Gràcia, 2005). Teachers and students were asked to identify those activities they had proposed or carried out throughout the academic year to learn the content of their subject.

The results of this study show differences between the tasks proposed and carried out in the different educational levels. More specifically, the tasks that appeared to be significantly more proposed and/or carried out at the university than in previous educational stages are: taking and organizing notes; writing practice reports, and writing a synthesis of two or more written sources. On the contrary, the tasks that seem to be proposed and/or carried out

\footnotetext{
${ }^{1}$ The research is developed by one of the research subgroups within the European project COST Action IS0703: Improvement of Writing in Education and the Workplace.
} 
with a significantly lower frequency at the university are: summarizing; writing concept maps from a text; writing text analysis; writing a reflection on one's own learning, and copying.

If we focus on the characteristics of the tasks according to their frequency of proposal or development (Miras, Gràcia, \& Castells, 2005), those which are most frequently assigned by teachers and solved by students shared some characteristics. These tasks, which were seldom assessed, were considered easy by both teachers and students, and they also agreed that the main source of information used to solve the tasks was the textbook and that such tasks were set and carried out on an individual basis. With regard to the type of learning promoted, teachers regarded note-taing as promoting the acquisition of new knowledge, and reading a text and summarizing as deepening knowledge and establishing relations with other knowledge.

The least frequently assigned and performed tasks were perceived as difficult by both teachers and students. In particular, the students stressed the difficulty involved in writing an essay and reflecting on what one has learned in writing. The teachers, on the other hand, stated that they suggested students should use sources other than the textbook as the primary source for carrying them out. These tasks were also assigned and carried out on an individual basis and, with regard to the type of learning such tasks promote, the teachers pointed out that they all promote deepening knowledge. Finally, these tasks were always assessed.

Moreover, tasks and writing practices seemed to vary according to the area of knowledge (Solé \& Castells, 2004). Thus, university teachers in the area of social sciences reported having proposed analyses and essays more frequently than teachers in the area of natural sciences who, on the contrary, proposed writing practice reports and organizing notes more frequently. These considerations provide us with an insight into why other research studies dealing with the students' representation of writing (Castelló, 2000) find that only 1\% of students report using writing to learn, whereas $57 \%$ of students relate writing with the possibility to improve remembrance of previously worked on knowledge.

Regarding teaching, writing remains to be scarcely taught at the Spanish university Mateos \& Solé, 2009; Castelló \& Iñesta, 2012). We do not have writing centers or writing programs as part of the institutionalized curricula. Some particular initiatives might be developed in some universities, but they are not frequent neither known by the rest of the universities. Especially at a Masters level, some writing courses or workshops have been developed 
but they are still isolated experiences (Castelló, Iñesta, Miras, Solé, Teberosky \& Zanotto, 2007; Solé, Teberosky \& Castelló, 2012; Tolchinsky, Escofet \& Rubio, 2003). Something similar happens at a doctoral level although in this context the interest on writing and the need to provide some guidelines to the students in order to help them finish their dissertation and publish scientific articles is increasing much faster (Castelló, Iñesta \& Monereo, 2009; Castelló, González \& Iñesta, 2010).

Given this scenario, it seems possible to assume that most teachers - probably not allimplicitly consider that writing should not be taught at the University and that helping students in academic genre acquisition is not part of their work, especially at the undergraduate level. This would explain why such activity is not present in their regular teaching practices. The situation described in this introduction may have changed with the entrance into the European Higher Education Area, which has involved the emphasis and promotion of continuous assessment, a system that may have increased the presence of writing-related activities. In order to obtain contrasted data on this matter and to therefore have a more current vision on academic writing at the university, we carried out the descriptive study we present in the following section.

\section{Objetives}

With the aim of exploring the role of writing practices and genre teaching at the university in our country, we carried out a descriptive study focusing on teachers' perceptions. In particular, our study aimed at answering the following questions:

1. What importance does academic writing have to promote university teaching and learning in comparison to other didactic elements?

2. What perception do teachers have about their students' degree of competence in academic writing in comparison to other academic competences?

3. Which kinds of academic writing tasks are assigned and how frequently throughout a six-month course?

4. Which criteria are used to assess the quality of an academic text? 


\section{Method}

\section{Participants}

Participants in this study were 106 teachers from 4 Spanish universities (UAB, UB, URL, and UAM) (see Table 1) teaching in different knowledge areas, although most of them taught in the field of Psychology (see Table 2). 54.7\% were women and $45.3 \%$ men. By age, $94.4 \%$ of subjects belonged to the 30-60-year-old group, with the 40-49-year-old group being the most frequent with $42.5 \%$ of cases (see Table 3). $54.8 \%$ of participants had more than 15 years of teaching experience, with the most experienced group (more than 20 years of experience) being the one with a higher percentage of cases (34\%) (see Table 4). The participants' first languages (L1) were Spanish (67\%) and Catalan (33\%).

Table 1. Number of teachers and percentages according to the Spanish university where they teach.

\begin{tabular}{lcc}
\hline \multicolumn{1}{c}{ University } & Number of teachers & Percentage \\
\hline $\begin{array}{l}\text { Autonomous University of } \\
\text { Barcelona (UAB) }\end{array}$ & 4 & 3.8 \\
$\begin{array}{l}\text { Autonomous University of } \\
\text { Madrid (UAM) }\end{array}$ & 47 & 44.3 \\
University of Barcelona (UB) & 24 & 22.6 \\
Ramon Llull University (URL) & 31 & 29.2 \\
Total & 106 & 100.0 \\
\hline
\end{tabular}


Table 2. Number and percentage of participants according to main area of knowledge of their subject.

\begin{tabular}{lcc}
\hline Areas of knowledge & No. of teachers & Percentage \\
\hline Arts, design, and architecture & 1 & .9 \\
Sciences & 2 & 1.9 \\
Social Sciences/Others & 8 & 7.5 \\
Social Sciences/Psychology & 79 & 74.5 \\
Teacher Training & 11 & 10.4 \\
Humanities & 3 & 2.8 \\
Others & 2 & 1.9 \\
Total & 106 & 100.0 \\
\hline
\end{tabular}

Table 3. Number and percentage of teachers according to their age group.

\begin{tabular}{lcc}
\hline Age group & No. of teachers & Percentage \\
\hline $20-29$ & 1 & .9 \\
$30-39$ & 29 & 27.4 \\
$40-49$ & 45 & 42.5 \\
$50-59$ & 26 & 24.5 \\
$60+$ & 5 & 4.7 \\
Total & 106 & 100.0 \\
\hline
\end{tabular}

Table 4. Number and percentage of participants according to years of university teaching experience.

\begin{tabular}{lcc}
\hline Years of teaching experience & Frequency & Percentage \\
\hline $0-4$ & 13 & 12.3 \\
$5-14$ & 35 & 33.0 \\
$15-20$ & 22 & 20.8 \\
More than 20 & 36 & 34.0 \\
\hline
\end{tabular}

\section{Instrument}

To collect the answers to our questions, we used a translated and adapted version of the Writing Skills Appreciation Inventory, developed by Kruse (2009), which includes five questions, 4 of them with a 5-point Likert scale and one of them with an open answer. The 
first question asks about the importance attributed to eight didactic elements to promote the teaching and learning of content worked in class (teamwork, oral presentations by students, reading and comprehension of scientific texts, academic writing, taking notes during class, debates, exam preparation, and ICT use). The second question asks about the level of competence students show in the previous eight elements, according to the teachers' experience. The third question asks about how frequently they ask their students to develop different academic writing activities (text analysis, essay, answers to an open-question exam, report based on source consultation, practice report, other texts) in a six-month course. The fourth question asks them to describe the characteristics of the texts assigned to students, different from the ones in question three. The last question asks about the importance they attribute to different aspects in an essay, article or thesis in their discipline (a total of 26 formal, rhetorical, and content aspects). In the second part of the questionnaire, 6 questions were included to explore the characteristics of participating teachers (age, gender, main area of knowledge of their classes, years of teaching experience, mother tongue, and studies of their classes) (Spanish version of the questionnaire could be accessed through:

https://spreadsheets.google.com/viewform?formkey=dE01dnYyR1IxUEFSWGZ6Z091dF9pT Gc6MQ ).

\section{Procedure}

The questionnaire was sent by email to the list of teachers in the Graduate School of Psychology of UAM, UB and URL, the Department of Developmental and Educational Psychology of the Teacher Training School at the UAM and UAB and to the Educational Sciences teachers of the URL. Participation was voluntary, and they were given 20 days to send their answers back by email. Data were collected between November and December 2010.

\section{Data analysis}

Statistics descriptive analyisis were performed using the SPSS v17.0 software. Means and Standard Deviation were calculated for each section of the questionnaire. 


\section{Results}

Importance of the different didactic elements to promote teaching and learning

As shown in Table 5, with regard to the importance university teachers attribute to the different didactic elements used in their classes to teach and promote learning, academic writing, together with reading and comprehension of scientific texts, is the tool with the highest score (with mean scores being higher than 4). Likewise, with the exception of note-taking, with a mean score lower than 3 , the other didactic elements (teamwork, oral presentations, debates, exam preparation, and ICT use) are assessed as important (with mean scores between 3.22 and 3.77).

Table 5. Importance given to different didactic elements used by university teachers: Means and standard deviations.

\begin{tabular}{lcc}
\hline Didactic element & Importance mean & Standard deviation \\
\hline Teamwork & 3.62 & $(1.009)$ \\
Oral presentations by students & 3.36 & $(1.088)$ \\
Reading and comprehension of scientific & 4.13 & $(.927)$ \\
texts & & \\
Academic writing & 4.09 & $(.787)$ \\
Taking notes in class & 2.83 & $(1.134)$ \\
Debates & 3.77 & $(.939)$ \\
Exam preparation & 3.22 & $(1.042)$ \\
ICT use & 3.33 & $(1.093)$ \\
\hline
\end{tabular}

Academic competences acquired by students

Although reading and writing are the most valued tools to promote teaching and learning according to teachers, they also consider that these are the competences that students acquire less (with means corresponding to degree of acquisition of these competences being 2.18 and 2.25, respectively). Moreover, it is in relation with these two competences where there is more agreement among teachers, with the lowest standard deviations. Teachers consider that their students are not very competent in teamwork, oral presentations, and debates (with means lower than 3), and a little more competent in note-taking, exam preparation, and ICT use (with means higher than 3, although not reaching 4). As shown in Table 6, among those competences that teachers consider students to have better acquired there are the two 
most traditional competences in university learning: note-taking and exam preparation. The competence of ICT use is the one that teachers assess with best acquisition (with a mean score of 3.65).

Table 6. Mean level of acquisition of academic competences that university teachers give to students and standard deviations.

\begin{tabular}{lcc}
\hline Competences & $\begin{array}{c}\text { Mean level of acquisi- } \\
\text { tion }\end{array}$ & Standard deviation \\
\hline Teamwork & 2.73 & $(.889)$ \\
Oral presentations & 2.58 & $(.946)$ \\
Reading and comprehension of scientific & 2.25 & $(.863)$ \\
texts & & \\
Academic writing & 2.18 & $(.860)$ \\
Taking notes in class & 3.35 & $(1.060)$ \\
Participating in debates & 2.69 & $(.999)$ \\
Exam preparation & 3.27 & $(.900)$ \\
ICT use & 3.65 & $(.884)$ \\
\hline
\end{tabular}

Types and frequency of academic writing tasks proposed by teachers

The importance that teachers attribute to academic writing as a tool for university teaching and learning contrasts with the low frequency in which they assign different academic writing tasks to their students (see Table 7). Never does the mean reach 3, which is equivalent to a frequency of 2-3 times throughout the term. If the different tasks are compared, those proposed with higher frequency are writing an assignment after source consultation and text analysis (with means of 2.89 and 2.85, respectively), followed by writing a practice report or similar (with a mean of 2.74), and with writing an essay and answering the open questions of an exam being the less proposed ones (with means of 2.20 and 2.08, respectively). 
Table 7. Mean frequency of assignments to carry out academic writing tasks throughout a term and standard deviations.

\begin{tabular}{lcc}
\hline Academic writing tasks & $\begin{array}{c}\text { Mean frequency of } \\
\text { assignment per } \\
\text { term }\end{array}$ & Standard deviation \\
\hline Text analysis in writing & 2.85 & $(1.293)$ \\
Writing an essay & 2.20 & $(1.108)$ \\
Answering an open-question exam & 2.08 & $(.829)$ \\
Writing a report after consulting two or & 2.89 & $(.949)$ \\
more sources & & \\
Writing a report (practice or similar) & 2.74 & $(1.198)$ \\
Other texts & 2.73 & $(1.197)$ \\
\hline
\end{tabular}

Among other types of texts that teachers propose to their students with a mean frequency of 2.73 (between once and 2-3 times throughout the term), there are case analyses, writing PowerPoint presentations, answering questions about a text, diaries, autobiographies, reflections or assessments about their own learning, argumentations and opinion texts, writing summaries, writing intervention or research projects, writing creative texts (poems, tales, etc.), and participating in blogs or forums.

\section{Assessment criteria for academic texts}

With regard to the quality assessment criteria for academic texts (essay, article or thesis), teachers assess all the aspects listed as important (with mean scores being between 3.20 and 4.47) (see Table 8). Among the text aspects with highest scores (mean scores higher than 4), there are, in order of importance: clear and logical structure (4.47), critical thinking (4.47), text intelligibility (4.41), appropriate approach to the problem (4.32), precise terminology (4.26), presence of a clear point of view (4.17), proper use of language (4.15), use of relevant literature (4.13), and arrangement and interpretation of research results (4.12). With mean scores between 3.5 and 4, there are the following criteria, in order of importance: originality in the argumentation (3.87), precision in bibliographical references (3.83), planning of writing process (3.73), presence of a table of contents (3.72), scientific style (3.71), discussion of scientific theories (3.62), complying with deadlines (3.60), precise literature summaries (3.58), complete bibliography (3.58), and use of writing to acquire new knowledge (3.58). 
Table 8. Mean level of importance of criteria to assess quality of academic texts (essay, article or thesis) according to university teachers and standard deviations.

\begin{tabular}{lcc}
\hline Assessment criteria for academic texts & Mean scores & Standard deviation \\
\hline Using relevant literature & 4.13 & $(.718)$ \\
Proper use of language & 4.15 & $(.790)$ \\
Precise terminology & 4.26 & $(.694)$ \\
Precise literature summaries & 3.58 & $(.816)$ \\
Planning of writing process & 3.73 & $(.857)$ \\
Clear and logical structure & 4.47 & $(.620)$ \\
Presence of a clear, personal point of view & 4.17 & $(.654)$ \\
Arrangement and interpretation of research & 4.12 & $(.765)$ \\
results & & \\
Precision in bibliographical references & 3.83 & $(.822)$ \\
Critical thinking & 4.47 & $(.693)$ \\
Scientific style & 3.71 & $(.873)$ \\
Use of tables and figures in the text & 3.33 & $(.825)$ \\
Discussion of scientific theories & 3.62 & $(.899)$ \\
Complete bibliography & 3.58 & $(.924)$ \\
Use of writing to learn new knowledge & 3.58 & $(.935)$ \\
Complying with deadlines & 3.60 & $(.943)$ \\
Grasping the effect of the text on the reader & 3.20 & $(.786)$ \\
exactly & & \\
Avoiding subjective opinions and statements & 3.37 & $(.908)$ \\
Presence of a table of contents & 3.72 & $(.859)$ \\
An interdisciplinary approach & 3.41 & $(.837)$ \\
Text intelligibility & 4.41 & $(.697)$ \\
Appropriate approach to the problem & 4.32 & $(.864)$ \\
Originality in the argumentation & 3.87 & 3.47 \\
Practical relevance & 3.46 & \\
Forceful defence of a thesis & & \\
\hline
\end{tabular}

Finally, with mean scores between 3 and 3.5, in order of importance, there are the following text aspects: practical relevance (3.47), forceful defence of a thesis (3.46), interdisciplinary approach (3.41), avoiding subjective opinions and statements (3.37), use of tables and figures (3.33), and grasping the effect of the text on the reader exactly (3.20). 


\section{Discussion and Conclusions}

The objective of this study was to explore from the teachers' point of view the writing practices that are developed in university education in Spain and, more specifically, in the fields of Psychology and Education. For those teachers participating in our study all the academic writing practices as well as scientific reading are important tools for learning disciplinary knowledge. Nevertheless, they do not frequently ask students to write, as it is also shown by other studies in different contexts (Delcambre \& Donahue, 2012; Solé et al., 2005). Besides, they consider that their students are not highly competent in writing to learn, although they consider them slightly more competent regarding note-taking, which has been traditionally a writing practice directly associated to learning (Castelló \& Monereo, 2005). This result would be in line with those obtained in previous studies (Solé et al., 2005; Miras, Gràcia, \& Castells, 2005; Mateos et al., 2007), according to which note-taking is the writing-to-learn task which is most frequent among Spanish undergraduate students and, therefore, the one they would be most familiar with. All in all, these results offer a complex picture. On the one hand, teachers value writing-to-learn in their disciplines, but they do not ask students to write very frequently. On the other hand, teachers consider that students are not competent enough to use writing as a learning tool. It seems that although they recognise the importance of writing to learn they are not used to reflect on how to use it in their disciplines.

Regarding the most frequent kinds of writing practices, according to the results obtained, the writing practices and genres proposed with the highest frequency by psychology and educational sciences teachers' are writing an assignment after source consultation and text analysis, followed by writing a practice report or similar, and with writing an essay and answering the open questions of an exam being the less proposed task. These results are coherent with those obtained in previous studies (Solé et al., 2005; Miras, Gràcia, \& Castells, 2005; Mateos et al., 2007). Nevertheless, as Lea \& Stierer (2000) and Chitez \& Kruse (2012) noted, it is reasonable to guess that the meaning of the writing tasks can vary dramatically from one teacher to another. Therefore, we can infer that the most frequently proposed assignment -writing an assignment after source consultation- may involve solving some general demands such as: "from your perspective, which is the author's (or text) perspective?", "Is this (a concept or topic) related to what we have been discussing in class?", "Do you think the proposal is useful (necessary, interesting, practical, etc...)? Why?" 
Something similar happens with the other genres such as, for example, writing a practice report. We can assume that this has to do with the explanation -frequently justifiedof the activities carried out during a period of practice (usually developed in professional contexts), but the specific requirements of this report are not clearly established among the universities and in each institution and each teacher can define them differently.

According to the importance that teachers attribute to the different criteria used to assess the quality of the academic texts, we can say that what they most highly value are elements related with clarity, organization and precision such as textual logic and structure, terminological precision, the presence of a clear point of view, the use of appropriate language or the revision of relevant literature. These criteria could be related to what they probably consider to be close to a better academic text. From previous studies, we know that experts devote an important part of their regulation activity when writing scientific articles to struggle with issues related to clarity and language precision as well as to textual logic and structure (Iñesta \& Castelló, in press). Data from doctoral students' text revision also revealed that these issues are among the most frequent worries and detected problems when they collaboratively review their texts (Castelló, González \& Iñesta, 2010). In sum, it seems that teachers, expert writers and advanced students in our context consider academic texts need to be clear and precise and their structure and textual logic should become clear for the reader.

Moreover, while the presence of a clear, personal point of view is also one of the highly valued criteria for teachers, data also show that among the less valued criteria are avoiding subjective opinions and statements, forceful defense of a thesis or grasping the effect of the text on the reader, which seems to be clearly contradictory. We consider that this contradiction may be related to the notions of objectivity and authorship. Some studies have illustrated the difficulties students have to make visible their voice and positioning in texts (Rinck \& Boch, 2012; Rinck, 2006; Castello, Iñesta, Pardo, Liesa \& Martínez-Fernández, 2011) as well as others have pointed out the relationship between authorship, text and the notion of objectivity (Castelló, in press). From these studies, it seems that students understand objectivity as opposite to positioning. This could have to do with the students' alignment with the idea that academic texts are objective because statements are based on facts, ignoring that although one of the academic requirements in research has to do with the presentation of knowledge as relative argument based on accumulated evidence, this should be done -at least in social sciences- on the basis of a result of a complex balance of assertion, caution, and evaluation of 
existing positions (Read, Francis \& Robson, 2001). As several authors have pointed out, academic writing in social sciences places a high value on the recognition of the relativity of knowledge and the presentation of a variety of informed arguments is as valued -in some cases even more- than the presentation of facts (Lea \& Stierer, 2000).

Our results are in line with these previous ones referred to students and support the hypothesis that teachers participating in our study consider academic texts to be normative, should use a precise lexicon and a fixed structure and these ideas enter into contradiction with the possibility to students position themselves although they are asked to maintain a clear and a personal point of view.

Finally, those criteria more related to formal and content dimensions such as detailed summaries, complete bibliography or use of tables and figures are also among the less valued ones. This could reinforce the idea that academic texts should be clear and well structured and have a precise vocabulary and that these criteria should be accomplished in first instance. Then, other caractherisitics are placed in second or third level of importance.

One of the limitations of the study is related to the specificity of genres and writing practices in the different disciplines. Unfortunately, from the collected data, we are not able to answer this question since we do not have enough participants of different disciplines nor we know previous studies in our country addressing this issue. Our results are related -and limited- to those genres and writing practices which have appeared as important for the Psychology and Education teachers of our sample, these results can be considered a starting point in the study of genres in those disciplines at Spanish Universities.

A second limitation has to do with the nature of the collected data which make it impossible to deepen or knowledge on the nature and the difficulties students experience when trying to deal with each of the genres they need to master. In this sense, some previous studies revealed that students when writing their undergraduate thesis (or their end-of-studies dissertation) experienced important difficulties in understanding the dialogical use of citations. Intertextuality is linked to almost only authoritative uses of citation but hardly ever to a more dialogical use of a source. Students evidenced great difficulties for discussing and even more for criticising the work of those cited sources in their texts. This was linked to the fact that it was also difficult to maintain visible the writer's position or stance all along the text (Castelló, Iñesta, Pardo, Liesa \& Martínez-Fernández, 2011; Rinck \& Boch, 2011). Future research 
should combine data from multiple sources such as final texts, drafts and interviews to explore and make a more grained analysis of this weakness and strengths of students when writing different genres and dealing with all the variety of writing practices at the university.

\section{Acknowledgements}

The study has been partially supported by the following projects:

-The Country Study Reports developed by the WG2-European project COST Action IS0703: Improvement of Writing in Education and the Workplace.

-Coordinated project «Reading and writing to learn at university» (EDU2009-14278-C02-01 and EDU2009-14278-C02-02 from the Spanish Ministry of Science and Innovation).

-Project on "Professional identity of university professors through the Critical Incident Analysis" (EDU2010-15 211 from the Spanish Ministry of Education and Science).

-Project on "Learning to write the undergraduate dissertation" (MQD.2009/2012_006) from the FPCEEB of the Ramon Llull University 


\section{References}

Bereiter, C. \& Scardamalia, M. (1987). Psychology of written composition. Hillsdale, NJ: Erlbaum.

Castelló, M. (2000). Students' conceptions on academic writing. In A. Camps \& M. Milian (Eds.), Metalinguistic Activity in Learning to Write (pp. 49-78). Amsterdam: Amsterdam University Press.

Castelló, M. (2007). El proceso de composición de textos académicos. In Castelló, M. (Coord.). Escribir y comunicarse en contextos científicos y académicos. Conocimientos y estrategias (pp. 47-82). Barcelona: Graó

Castelló, M. (2009). Aprender a escribir textos académicos: ¿copistas, escribas, compiladores o escritores? In J. I. Pozo \& M. P. Pérez Echevarría (Coords.). Psicología del aprendizaje universitario: la formación en competencias (pp.120-133). Madrid: Morata.

Castelló, M. (in press). Fostering the development of academic writing, identity and voice when writing the end-of-studies dissertation; students' knowledge and conceptions In I. Delcambre \& D. Lahanier-Reuter (Eds.) International studies on writing at university: comparisons and evolutions. Perspectives on Writing Series (The WAC Clearinghouse)

Castelló, M. González, L. \& Iñesta, A. (2010). La regulación de la escritura académica en el doctorado: El impacto de la revisión colaborativa en los textos. Revista Española de Pedagogía, 247, 521-537.

Castelló, M. \& Iñesta, A. (2012). Texts as artifacts-in activity: Developing authorial identity and academic voice in writing academic research papers. In M. Castelló \& C. Donahue (Eds.). University writing: Selves and Texts in Academic Societies (pp 179-200). London: Emerald group Publishing Limited.

Castelló, M. (Coord.); Iñesta, A., Miras, M., Solé, I., Teberosky, A., Zanotto, M. (2007). Escribir y comunicarse en contextos científicos y académicos. Conocimientos y estrategias. Barcelona: Graó.

Castelló, M., Iñesta, A. \& Monereo, C. (2009). Towards self-regulated academic writing: an exploratory study with graduate students in a situated learning environment. Electronic Journal of Research in Educational Psychology, 9 (3), 1107-1130. 
(http://www.investigacion-psicopedagogica.org/revista/new/english/ ContadorArticulo.php?367

Castelló, M., Iñesta, A., Pardo, M., Liesa, E. \& Martínez-Fernández R. (2011). Tutoring the end-of-studies dissertation: helping psychology students find their academic voice. Higher Education (On-line first; published 01 April, 2011) DOI: 10.1007/s10734-0119428-9.

Castelló, M. \& Monereo, C. (2005). Students' note-taking as a knowledge construction tool. L1-Educational Studies in Language and Literature, 5 (3), 265-285.

Chitez, M. \& Kruse, O. (2012). Writing cultures and genres in European higher education. In M. Castelló \& C. Donahue (Eds.). University writing: Selves and Texts in Academic Societies (pp. 151-175). London: Emerald group Publishing Limited.

Delcambre, I. \& Donahue, C. (2012). Academic writing activity: Student writing in transition. In M. Castelló \& C. Donahue (Eds.). University writing: Selves and Texts in Academic Societies (pp. 129-149). London: Emerald group Publishing Limited.

Flower, L.\& Hayes, J. R. (1980). The dynamics of composing: making plans and juggling constraints. In L. W. Gregg \& E. R. Steinberg (Eds.). Cognitive Processes in Writing (pp. 3-30). Hillsdale New Jersey: Lawrence Earlbaum Associates.

Iñesta, A. \& Castelló, M. (in press). Towards an integrative unit of analysis: Regulation Episodes in expert research article writing. In C. Bazermann (Ed.) Writing Research Across Borders Conference Volume (temptative title), Parlor Press (accepted).

Kruse, O. (2009). Writing Skills Appreciation Inventory. ZHAW. Zurich University of Applied Sciences; School of Applied Linguistics.

Lea, M. R., \& Stierer, B. (2000). Student writing in Higher Education: New Contexts. Buckingham: SRHE \& Open University Press.

Mateos, M. (2009). Aprender a leer textos académicos: más allá de la lectura reproductiva. In J. I. Pozo \& M. P. Pérez Echevarría (Coords.) Psicología del aprendizaje universitario: la formación en competencias (pp.106-119). Madrid: Morata.

Mateos, M., \& Solé, I. (2009). Synthesising information from various texts: a study of procedures and products at different educational levels. European Journal of Psychology of Education, 24 (4), 435-451. 
Mateos, M., Villalón, R., De Dios, M.J., \& Martín, E. (2007). Reading and writing tasks on different university degree courses: What do the students say they do? Studies in Higher Education, 32(4), 489-510.

Miras, M., Gràcia, M., \& Castells, N. (2005). Reading, writing and knowledge acquisition in Secondary, Post-Compulsory and Higher Education in Spain. In M. Pandis, A. Ward \& S. Mathews (Eds.), Reading, Writing, Thinking (pp. 130-138). Newark, DE, USA: International Reading Association.

Nelson, N. (2007). The Reading-Writing nexus in discourse research. In Ch. Bazerman (Ed.) Handbook of Research on Writing (pp. 435-450).New York: LEA.

Read, B. \& Francis, B., Robson, J. (2001). 'Playing Safe': Undergraduate essay writing and the presentation of the student 'voice'. British Journal of Sociology of Education, 22(1), 387-399.

Rinck F. (2006). Gestion de la polyphonie et figure de l'auteur dans les parties théoriques de rapports de stage, Lidil, 34, 85-103.

Rinck, F. \& Boch, F. (2012). Enunciative strategies and expertise levels in academic writing: How do writers manage point of view and sources? In M. Castelló \& C. Donahue (Eds.), University writing: Selves and Texts in Academic Societies (pp. 111-128). London: Emerald Group Pub. Ltd.

Solé, I. \& Castells, N. (2004). ¿Influye el dominio disciplinar en las tareas de aprendizaje? Leer y escribir para aprender en ciencias sociales y ciencias naturales. Lectura y Vida, 25(4), 6-17.

Solé, I., Mateos, M., Miras, M., Martin, E., Cuevas, I., Castells, N., \& Gràcia, M. (2005). Lectura, escritura y adquisición de conocimientos en Educación Secundaria y Educación Universitaria. Infancia y Aprendizaje, 28(3), 329-347.

Solé, I., Teberosky, A. \& Castelló, M. (2012) Academic communication strategies in postgraduate studies. In C. Thaiss (Ed.), Writing Programs Worldwide: Profiles of Academic Writing in Many Places. Parlor Press.

Teberosky, A.(2007). El texto académico. In M. Castelló (Coord.). Escribir y comunicarse en contextos científicos y académicos. Conocimientos y estrategias (pp.17-46). Barcelona: Graó. 
Tolchinsky, L., Escofet, A. \& Rubio, M. J. (2003). Tesis, tesinas y otras tesituras. De la pregunta de investigación a la defensa de la tesis. Barcelona: Edicions UB. 